\title{
REPRESENTED SPEECH AS A RHETORICAL DEVICE IN 10+ NIGHTS
}

\author{
Nguyen Thi Thu Thuy* \\ Hanoi National University of Education, 136 Xuan Thuy, Cau Giay, Hanoi, Vietnam
}

Received 13 August 2018

Revised 25 September 2018; Accepted 26 September 2018

\begin{abstract}
Represented speech has long been a subject of research in linguistics and literary criticism from a variety of perspectives. From a stylistic one, we conduct this study of represented speech in narratives with data from the novel 10+ nights by Hồ Anh Thái so as to clarify I.R. Galperin's view (1971) which posits that represented speech is a rhetorical device. The paper clarifies the following issues: (i) What is a rhetorical represented speech?, (ii) Is all represented speech in literary works a rhetorical device?, and (iii) If not, what are unique characteristics of rhetorical represented speech? The major methods used in this study include: classification (classifying types of represented speech), description (describing types, patterns and linguistic features of represented speech), and rhetorical analysis (analyzing rhetorical values and impact of represented speech so as to generalize theoretical arguments). The data used for this study include direct represented speech that does not conform to regular rules. This paper starts with concepts of represented speech as a rhetorical device, followed by rhetoric represented speech in $10+$ nights and ways to identify rhetoric represented speech in $10+$ nights before the conclusion.
\end{abstract}

Keywords: represented speech, rhetorical device, narrative, stylistics, lead-in

\section{Concepts of represented speech as a rhetorical device}

Represented speech is normally regarded as part of utterances in literary works, but in fact, it occurs everywhere - in everyday speech, in public service and administrative settings, in media, in political pamphlets, or in academic writing. However, not all represented speech acts as a rhetorical device simply because represented speech is primarily the rendition of others' words in such situations as those occurring in literary works, especially in plays.

* Tel.: 84-936005573

Email: thuyvncsp@yahoo.com.vn
What is rhetoric represented speech? In Stylistics (1971), I.R.Galperin merely provides in passing a pioneering argument that represented speech is a rhetorical device (section on Represented speech, when discussing features of represented speech) without stating a clear definition of rhetoric represented speech. While analyzing represented speech, both pre- as well as post-Galperin stylisticians only dealt with such issues as definition of represented speech, characteristics of represented speech (semantics, syntax and configuration), types of represented speech and identification of represented speech, amongst others (Genette, 1972; Wale, 1989; Asher, 1994; Black, 2006). On the whole, these investigated represented 
speech as a way of organizing utterances rather than consider represented speech a rhetorical device, so they suggested no definitions of this rhetorical device.

We posit that represented speech is a rhetorical device (rhetoric represented speech, hereafter abbreviated RRS for short), since it is used to bring about certain rhetoric impacts on the expression of the content and intent of literary works and provide readers with novel impression. Our investigation reveals that among the three forms of represented speech, namely direct, indirect and free, the direct form can be utilized creatively so as to reach the best expressive effects. This is the reason why we decide to study direct represented speech in this paper (and our previous ones as well) and consider its rhetoric effects.

\section{RRS in $10+$ nights}

In narratives, represented speech always consists of the lead-in (of the narrator) and the actual words (of the character, or the quote). Also, it consists of linguistic elements, such as expressions that name the character, verbs of speaking, thinking or manner of speaking, amongst others, and possibly other elements describing the character's countenance, gestures, states of mind, etc. Graphically, quotes are placed after a colon in quotation marks on the same line or on another line with a dash at the beginning instead of quotation marks. A full-stop ends the quote before another line begins. Technically, the direct, actual words of the character are separated from the lead-in of the narrator. Lexically, in quotes, the first person is always used when the character is referring to him/herself, and quotes are normally of the spoken register. Grammatically, or structurally, verbs are conjugated in the
Present tense (in inflectional languages), and the sentence occurs as direct forms of interrogative, exclamative or imperative utterances, together with appropriate punctuation marks. The represented speech that comprises all of these features is an ordinary one, which is trivial and void of rhetorical values and impact; it is by no means a rhetorical device, so it is not the subject of our research.

Examining $10+$ nights by Hồ Anh Thái, we could collect 242 instances of direct represented speech as a rhetorical device out of a total of 290 instances of represented speech in the novel. Hereafter the paper will classify and present specific features of direct represented speech as a rhetorical device (in the view presented above in Section 1).

\subsection{Composition and patterns of rhetoric represented speech}

Our investigation reveals that rhetoric represented speech (RRS) in 10+ nights mostly occurs as (i) intertwined speech of both the character and the narrator (217 out of 242), and (ii) utterances of several characters, which formulates dialogues (25 out of 242).

\subsubsection{Speech of one character intertwined} with that of the narrator

These direct RSs in 10+ nights appear in the following pattern:

Pattern 1: Lead-in + Quote

2.1.1.1. The lead-in in this pattern falls into 3 types:

a. The lead-in is a declarative statement that includes a verb of speaking and occurs sequentially to others without any graphic signs to separate it from the quote. In terms of position, it may precede or follow the quote, e.g.

(1) Mỗi cô dắt về là một cuộc khởi đầu. Tất nhiên phải được giới thiệu trân trọng. $M e$ 
ơ đây là đây là. ${ }^{(1)}$ Bà mẹ gạt đi ngay... (Hồ Anh Thái, 2007, p. 18)

Each girl introduced was a beginning ${ }^{1}$. Naturally they had to be introduced formally. Mom, this is so-and-so. The mother instantly diverged from the topic. ${ }^{2}$

b. The whole RS is a narrative, including an $\mathrm{S}-\mathrm{V}$ construction consisting of verbs of speaking without graphic signs to separate it from the quote, e.g.

(2) Đạo diễn bảo tại kĩ thuật non kém của ta làm hỏng phim tôi. (Hồ Anh Thái, 2007, p. 157)

The director said that our poor technology ruined my movie.

c. The lead-in occurs as a normal construction, with verbs of speaking or manner of speaking, separated from the quote with colon (:), e.g.

(3) Vẫn cái giong kia leo lẻo: số điện thoại này hiện không liên lạc được xin quý khách vui lòng goi lại sau. Thì thế, ít ra cũng gieo lại một tí hi vọng để còn chờ đến một lần sau tuyệt vọng.

The same voice twitters: The number you call is currently unavailable. Please call again later. Well, so, at least it sows a bit of hope for another time waiting in vain.

Among the 3 types, (a) is used the most, with 87 out of 137 instances while (b) and (c) occur less, with 26 and 24 out of 137 instances respectively.

2.1.1.2. The quote in this pattern is structured as 3 types:

a. The quote is a sentence, grammatically very much like a statement (with punctuation

1 The examples are presented in the following format: the underlined is the lead-in, and the italicized is the quote. These graphical representations are ours, not in the original.

2 The translation here is mere literal rendition rather than refined literary re-creation of the original for the sake of readers' understanding. marks), separated from the lead-in as an independent one (example (1)), and without graphic markers of direct speech;

b. The quote is part of the sentence (normally a complement after verbs of speech, as in (2)), but is not separated from the lead-in and without graphic markers of direct speech;

c. The quote is part of the statement but structured as a sentence which is separated from the lead-in by a colon (:), with the initial letter normally capitalized (as in (4)), or not (as in (3)), e.g.

(4) Thiếu phu có câu cửa miệng với những người đàn ông đến chơi nhà: Thô $i$ về làm gì, ở lại đây mà ngủ cho vui. Cho vui. Trắng mặt ăn tiền. Ai muốn nói mình dễ dãi cũng mặc. Ai vui tính thì coi là đùa. Ai tin thật thì ở lại thì đúng là thật. (Hồ Anh Thái, 2007, p. 71).

The lady always said to her male visitors: What are you heading home for, just stay here overnight for fun. For fun. Shameless to make money. Who says I am a slut, I don't care. To humorous people this is a joke. To those who believe in the words and stay, things would turn out that way.

\section{Pattern 2: The quote}

This occurs alone as a quote "mingled" among statements, e.g.

(5) Người đàn ông và người đàn bà cần có một căn phòng. Họ đến mượn căn hộ này của người bạn. Cần phòng à, ôkê, quá đonn giản. Người bạn tỏ vẻ thông cảm hiểu biết... (Hồ Anh Thái, 2007, p. 8).

The man and the woman needed a room. They borrowed this apartment from a friend. Need a room, ok, a mere piece of cake. The friend appeared empathic...

or part of a statement, e.g. 
(6) Đêm đêm công nhân vệ sinh vẫn còn phải xách đèn chai nện ủng cồm cộp đi vào ông ơ mở cứa cho tôi thay thùng. (Hồ Anh Thái, 2007, p. 13).

Each night, sanitation workers had to stamp their boots, with a light in a bottle in their hands, please open the door for me to replace the toilet bucket.

The quote in this pattern is always a sentence (as in (5) and (6)) although graphically there is no indication (initial letter not capitalized, no punctuation mark at the beginning of a sentence, as in (6)).

Pattern 1 was used more by Hồ Anh Thái (137/217 instances) while Pattern 2 was used less (80/217 instances).

\subsubsection{Quotes from several characters} (conversations)

Like quotes from one character, quotes from different characters appear in two forms:

Pattern 3: Lead-in + Conversation

2.1.2.1. There are two types of lead-in in this pattern:

a. Only one lead-in for the whole conversation. The lead-in is normally presented together with utterances in the conversation and separated from the characters' utterances by a comma (,). The lead-in can be put in the final utterance, e.g.

(7) Chính xác tình trạng của người đàn ông khi bị kẹt lại trong căn hộ này. Điện thoại di động đời mới nhiều chức năng gọi cho bạn bè. Tìm cho tớ xem ông trồng chuối hột ở đâu? Nộm hoa chuối à, tớ biết một nơi nhậu có nộm hoa chuối đậm đà khó quên, đến nhà hàng ở Láng Hạ nhé. Khỉ gió, người đàn ông phải văng tục ra. (Hồ Anh Thái, 2007, p. 28).

Exactly the situation of the man who got stuck in the apartment. New types of mobile phones have more functions when calling friends. Find me the banana grower? Banana flower salad, I know a restaurant with banana flower salad, unforgettable taste, come to the one on Lang Ha Street. Dammed you, the man had to swear.

Alternatively, the lead-in can be in the initial utterance, e.g.

(8) Nói tiếp câu nữa, không phải nộm hoa chuối, lão họa sĩ trồng chuối hột ấy. Cái gì? Thằng chuối hột nó làm sao? Nó nợ nần gì mày? Sao nói năng gì nhu kẹt băng thế? (Hồ Anh Thái, 2007, p. 29).

Another utterance continues, not banana flower salad, the artist who grows banana. What? What with the banana grower? He owes you anything? Why mumbling as if there's a nut in your mouth?

Another form of lead-in is like a statement that is separated from the conversation, e.g.

(9) Chín giờ ba mươi mới có hồi âm của kẻ thứ hai. Cho tao gui loi chia buon. Tao dang o sai gon di choi cho lon, khong ra duoc.

May khong ra duoc nhung may co the bao mot thang nao di tim thang Hoa Si Chuoi Hot, bao no ve ngay. (Hồ Anh Thái, 2007, p. 31).

Response from the second did not come until 9:30. Send him my sympathy. I am in Sai Gon, visiting Cho Lon now, cannot come there.

You can't come but you can ask some guy to find the Banana Artist and tell him to come back instantly.

b. A conversation may have different lead-ins to utterances of various characters, although there may not be lead-ins for every one of them. On the other hand, even when there is lead-in, both the lead-in and the quote are not graphically marked for identification. Sometimes it is impossible to distinguish the lead-in from the direct or indirect RS, e.g.

(10) Chuyện trò rộn ràng dẫn đến hỏi thăm về gia cảnh (i). Anh bảo anh hai vợ (ii). Anh 
gọi vợ hai ơi chào các dì đi (iii). Cô nhân tình khoanh tay chào (iv). Vợ hai nói chuyện với các dì cho vui đi (v). Cô Mơ Khô quay ra than phiền có anh chồng đào hoa đi đâu gái theo đó (vi). Mấy bà già rôm rả chèng đéc ơi, một lúc mần luôn hai zợ ngon lành, pháp luật có cho giấy kết hôn không con (vii)? Anh nói thản nhiên thuận vợ thuận chồng chẳng cần giấy tờ đâu các dì ơi, con chỉ sợ nhất là cả hai vợ đoàn kết đồng lòng bao vây cấm vận chồng (viii). Con làm sao cho công bằng zậy con (ix)? Con chia ngày, vợ một ngày chẵn, vợ hai ngày lẻ, chủ nhật thì góp gạo thổi cơm chung $(\mathrm{x})$. Tất nhiên cũng có ngày con nhầm, đi nhậu về lơ mơ nhầm một thành hai hai thành một (xi). Nhưng các cô ấy cũng tự giác, nhầm là tự ý gọi lái xe đến chở con trả về đúng nhà (xii). Không cô nào lợi dụng hoàn cảnh để xài thêm một suất (xiii). Thế là nhà yên (xiv). (Hồ Anh Thái, 2007, p. 143-144).

The lively talk led to inquiries of family circumstances (i). He said he had 2 wives (ii). He called my second wife, say hello to these aunts (iii). The lover folded her arms and said hello (iv). My second wife, please talk to the aunts (v). Mo Kho complained of having a Don Juan husband - girls follow him wherever he is (vi). The older women chatted boisterously oh my god, having two wives simultaneously, so good, any marriage certificate from the authority, guy (vii). $\underline{\mathrm{He}}$ replied shamelessly we get on well with each other and agree there's no need for that paper, what I fear most is that both wives join hands to ban their husband (viii). So how do you ensure fairness to both (ix)? Every other day, madams. First wife on even days, second on odd days, Sunday all together (x). Well, naturally sometimes I am confused. Drunk, I am confused between them (xi). Well, but they are fair and honest. If I am confused, they call my chauffeur to drive me to the right home (xii). Neither of them takes advantage of the circumstance to get more than agreed (xiii). So peace to all (xiv).

The RS in (3), (6), (7) and (8) are direct ones with lead-in, but are presented successively together with quotes without separating marks. RS (3) and (6) resemble both direct and indirect ones.

\subsubsection{Quotes in conversations are} largely a sentence or several sentences presented separately or as part of sentences together with lead-in. Graphically, quotes in conversations look livelier than quotes from single characters thanks to various punctuation marks (e.g. question marks at the end of utterances in (7), (8) and (10)).

\section{Pattern 4: Conversation}

Pattern 4 contains no lead-in but only the represented speech. There are 2 types in this pattern:

a. Type 1: Only the conversation appears between narrative parts. The author does not use any lead-in for utterances by different characters nor any separating marks. The whole conversation appears like a narrating part without clear direct utterances, and it is also difficult to identify who says what, e.g.

(11) Cả bốn gã đều ngớ cả ra. Nó bảo sai sai cái gì. Hợp đồng sai thì bố đứa nào dám kí. Thôi thì mày ki đi. Điên à, nhõ nó ghi tao nọ nó triệu đô tao cũng kí à. Còn tao không sợ triệu đô nhung cái hợp đồng dài ngoằng nọi dung Việt gian phản động diê̂n biến hòa bình thì sao. Thôi đợi họa sĩ cởi mở về. Mà lão biến đâu nhanh thế nhi? (Hồ Anh Thái, 2007, p. 41-42).

All the four guys were astonished. He says sign something, what to sign. Who dares to sign incorrect contracts. Ok, you sign it. Crazy, will I sign it if it says I owes him one million bucks. I do not fear one million bucks but what if that lengthy contract contains counter-revolutionary content against the government. Well, wait for the open-minded 
artist to come back. Where on earth has he vanished so quickly?

In this example, all the sentences from the second to the last one are conversation among 4 characters, but there are no leadins and no graphic marks to indicate who says what.

b. Type 2: No lead-ins for each character in the conversation, but there are graphics to identify them. Specifically, SP1 (speaker 1) is consistently marked with different lines and the quotation marks " ", while SP2 (speaker 2) is marked with different lines and the dash at the beginning, e.g.

(12) Thực đơn theo yêu cầu thực khách thì người cung ứng cũng có yêu cầu.

“Cháu cần mua một môbai chụp ảnh. Năm triệu. Sẽ có đủ thực phẩm cho chú ăn năm ngày nũa”.' (SP1)

- Sao biết chú cần ăn năm ngày nũa? (SP2)

"Cháu tạm tính vậy. Đồng ý chi năm triệu không chú?” (SP1)

- Chú cần biết là tiền ấy không dùng mua ma túy hay hùn vốn giải thưởng đua xe. (SP2)

"Cháu sẽ trình chú cái môbai mói. Hôm qua đứng choi Bò̀ Hồ, thấy cu rùa chĩa đầu lên mà không chup được. Bi mặt trước ban bè quá” (SP1) (Hồ Anh Thái, 2007, p. 221).

The menu meets diners' demands, so suppliers have demands too.

"I need a camera mobile phone. 5 million. Will supply you with enough food for 5 more days." (SP1)

- How can you know I need to eat for 5 more days? (SP2)

"I just guess. Agree with 5 million?" (SP1)

- I need to know that money is not for drug or contributing to racing prizes. (SP2).
"I will show you the new mobile phone. Yesterday I hanged around Hoan Kiem lake, and saw Old Turtle raising his head, but I couldn't take a shot. Lost my face while friends were around." (SP1)

Patterns 3 and 4 are used more frequently, with 11 and 14 out of 242 instances respectively, but much less than patterns 1 and 2 .

As the organization of lead-in and quotes in RRS in 10+nights analyzed above shows, graphically, unlike other novels by such authors as Nguyễn Huy Thiệp, where RRSs stand out with clear markers and boundaries, and both lead-in and quotes normally share the same structures (Nguyễn Thị Thu Thủy, 2016a), RRSs in 10+ nights are not in focus. Instead, they mingle with the narrator's words. Both the lead-in and the quote fall within the same statement or paragraph as if they were in the same speech flow. There are no graphic markers for the lead-in and quotes in most cases. All boundaries of direct speech are blurred and unmarked. However, Hồ Anh Thái’s RRSs resemble those of Nguyễn Huy Thiệp in that they are organized as a set of (repetitive) patterns with high density and frequency: 242 RRSs in 4 patterns out of 290 in $10+$ nights while Nguyễn Huy Thiệp uses 1140 RRSs of the same pattern in the total of $1180 \mathrm{RSs}$ in his 7 different novels (Nguyễn Thị Thu Thủy, 2016b). Such an RRS organization clearly demonstrates the author's artistic intent while generating novel, fascinating impressions on readers. This means various options avail for organizing RRSs, but it is important that RRSs should differ from normal RSs, and RRSs should be repetitive in a certain number so as to form a pattern. We believe this is a crucial feature of RRSs that apparently distinguishes them from normal RSs. 


\subsection{Word use in $R S$}

\subsubsection{Word use in lead-in}

In RSs with lead-in's, lead-in's mostly contain verbs of speaking (130/147), verbs of manner of speaking or expressions related to the presentation of speech. No instances are found to be without. Even if they appear, it is difficult to identify them as lead-in's because in most instances, they are presented as successive statements in the narrative flow.

\subsubsection{Word use in quotes}

Compared to lead-in's, words in quotes are much more lively and richer, which make the language moderner, newer and clearly direct speech. Also, it is this feature that enables readers to identify RRSs in $10+$ nights.

(i) Elements of direct speech are present, including exclamation, colloquial expressions, street slangs, dirty words, local vocabulary, dialectal pronunciation, foreign borrowings pronounced in the Vietnamese way, first and second persons, amongst others, e.g.

(13) Giáo sư Một hồn nhiên tin ngay lời khen: Đúng phóc, tui đang nói dở tới chổ ảnh hwởng của zăng mun phuơng Tây. Tui xing tiếp tục zới ảnh hưởng của zăng hóa Nga, Mỹ ở Ziệc Nam nưa cuối thế ki hai mươi. (Hồ Anh Thái, 2007, p. 201).

(13) Professor Mot naively believed the praise instantly: Right, ay was talkin' 'bout influences of Vestern [Western] civilization. Now allow me to continue with influences of Russian and American cultures on Vietnam in the later half of the $20^{\text {th }}$ century.

(with "đúng phóc" (right) being colloquial; while "tui" (ay = I), “chổ” (point), "zăng mưn" (civilization), "xing” (allow me), “zới” (with), "Ziệc Nam" (Vietnam): local dialect pronunciation).

(14) Thầy đuổi trò tồng ngồng chạy vòng quanh cái bục gỗ, thầy chửi bằng giọng miền trong nồng nặc như tiếng Ý. Tổ cha mi mi tù mô ra ri mần răng mà mi lại ra ri. (Hồ Anh Thái, 2007, p. 21)

The teacher chased the naked student around the wooden platform, and cursed him in the strong local dialect that sounds like Italian. Dammed you, how couldja turn out this way. (with "mi" (you), "mô" (where), "ri”" (this), "mần răng" (how) being dialectal vocabulary).

Particularly interesting is the fact that colloquial expressions, slangs, dirty words and borrowings are not only uttered by less educated characters but also educated ones, e.g.

(15) Hồng Kông khen thêm một tiếng ngon đilisớt. Nó bảo sốt sốt cái gì? Thịt chó không chấm sốt, đồ ngu. (Hồ Anh Thái, 2007, p. 41)

Hong Kong adds a praise that it's đilisớt [i.e. delicious]. He said what's sốt sôt. Dog meat does not need to dip in sauce, idiot.

(16) Giáo Sư Một cũng bất ngờ. Chếc me tui, hắng bỏ bom tui. (Hồ Anh Thái, 2007, p. 199)

Professor Mot was also startled. $\underline{P a w}$ [poor] me, he trapped me.

Such words uttered by intellectuals are meant to satire and mock at the vanity of city life, city people, the supposedly educated upper-class, and even villains in artist's disguise.

(ii) Most notable are youngsters' language.

$10+$ nights is updated with a system of modern language used by youngsters in their vibrant social life with different types of people and different ways of language use from all sources and walks of life, e.g.

(17) "Cháu sẽ trình chú cái môbai mới. Hôm qua đứng chơi Bò̀ Hồ, thấy cu rùa chĩa đầu lên mà không chup được. Bỉ mặt trước bạn bè quá" (Hồ Anh Thái, 2007, p. 221). 
"I will show you the new mobile phone. Yesterday I hanged around Hoan Kiem lake, and saw Old Turtle raising his head, but I couldn't take a shot. Lost my face while friends were around."

(iii) The presence of ready-made clichés, which are built-in recording (as in (3)), or lyrics of songs stored in phones, e.g.

(18) Chính vào lúc ấy một tiếng huýt sáo làm họ mở choàng mắt. Giai điệu không lời đúng vào cái câu mà họ đều biết. $V a ̀$ em đã biết nói tiếng yêu đầu tiên. Không huýt tiếp mà lặp lại. Và em đã biết nói tiếng yêu đầu tiên. (Hồ Anh Thái, 2007, p. 212)

Right then a whistle woke them up. The tune without lyrics was the one they knew: And you say the first word of love. No more whistling but repeating And you say the first word of love.

or idioms and proverbs, e.g.

(19) Vậy là bà thắc mắc. Vợ chồng nhu đũa có đôi. Uyên voong một cặp chẳng rời nhau ra. Người ta mong có đôi để mà đầu gối tay ấp, mong bám nhằng nhằng lấy nhau, mong còn chẳng được, mìn thì givơng cao ngon cờ độc lập tụ do. Cô có thân mà không biết suớng. Phải tay tôi ấy à, đi đâu cũng phải có ông có bà. Rõ là kẻ ăn không hết người lần chẳng ra chura kì ...

So she wonders. Couples are like a pair of chopsticks, a pair of pigeons that are never apart. People long to have partners to pillow talk, to stay together, but they may not succeed, while you cherish liberty. You don't know how to enjoy happiness. If I were you, I would never go anywhere alone, always in couple. Well, difference between the have and the haven 't...

(with "đũa có đôi” (a pair of chopsticks), "đầu gối tay ấp" (roughly translated as "pillow talk"), "kẻ ăn không hết người lần chẳng ra" (the have and the haven't) are popular Vietnamese idioms).

\subsection{Discussion on RRS in 10+ nights}

Based on the analysis above, it is possible to say that Hồ Anh Thái attaches high importance to the art of lead-in, as he creates novel ways of lead-in which are unique so as to bring about impressive impacts. This provides evidence to confirm the view that RS is a rhetorical device.

2.3.1. The most apparent feature of RS in $10+$ nights is the absence of graphic marks (colons, quotation marks, beginning a new line, dash at the beginning of the line, punctuation marks of direct speech like question mark, exclamation mark, etc.) to distinguish leadin's and quotes, or distinguish RS from normal narration. Almost all sentences in $10+$ nights contain the narrator's words, while few are marked as characters' utterances. Therefore, the narrator seems to dominate. Characters' words are presented successively in the narrative flow, which makes the reader feel that the narrator and the characters are one, and the characters' words mixed with those of the narrator. Thanks to that, it is easier for the narrator to depict the messy society where all values are turned upside down. Furthermore, the absence of graphic markers brings the readers closer and faster to the characters' words because they are not interrupted by colons or quotation marks. Also, the readers are fascinated with the curiosity to decipher who says what.

2.3.2. Lead-in's in $10+$ nights both ensure consistency and rules (as shown in the 4 generalized models and types), and freedom (as shown in a rich variety of forms apart from what was presented in 2.1), all of which endows Hồ Anh Thái's RS with diversity and strong, unique impression of the author's innovation in organizing speeches in his novel.

2.3.3. The introduction of colloquial language from all walks of life and social 
strata, clichés, idioms as well as modern vocabulary into characters' utterances gives RSs in $10+$ nights their irresistible attraction.

Generally speaking, Hồ Anh Thái did create various breakthroughs that bring the reader novel and thrilling impressions, and generate high impacts in expressing his ideological content and intent in the novel.

\section{Ways to identify RRS in 10+ nights}

As is seen, it is by no means easy to identify RS in 10+ nights since almost all RSs in the novel are unmarked; there are almost no formal indicators. Therefore, we posit that in order to identify RS here, apart from regular graphical markers or lexical indicators, it is necessary to refer to other factors, especially indicators of direct speech. In sum, we can rely on:

3.1. Graphics (colons after the lead-in; quotation marks, dash at the beginning of the line before the quote, comma, question mark, exclamation mark at the end of the quote) in case there are graphics.

3.2. Lexical indicators, including verbs of speaking, verbs of manner of speaking or speech-related words if one wants to find the lead-in.

Meanwhile, quotes can be identified through:

- Elements of direct speech: first person pronouns, exclamation words, colloquial expressions, slangs, dirty words, foreign borrowings pronounced in the Vietnamese ways, etc.,

- Ready-made expressions: built-in recordings in phones, song lyrics, popular idioms and proverbs, amongst others.

\subsection{Speech acts}

Let us return to example (11):

(11) Cả bốn gã đều ngớ cả ra (i). Nó bảo sai sai cái gì (ii). Hơp đồng sai thì bố đứa nào dám ki (iii). Thôi thì mày kí đi (iv). Điên à, nhõ nó ghi tao nơ nó triệu đô tao cũng kí à (v). Còn tao không sợ triệu đô nhung cái hợp đồng dài ngoằng nội dung Việt gian phản động diễn biến hòa bình thì sao (vi). Thôi đợi họa sĩ cởi mở về (vii). Mà lão biến đâu nhanh thế nhi (viii)? (Hồ Anh Thái, 2007, p. 41-42).

All the four guys were astonished (i). He says sign something, what to sign (ii). Who dares to sign incorrect contracts (iii). Ok, you sign it (iv). Crazy, will I sign it if it says I owes him one million bucks (v). I do not fear one million bucks but what if that lengthy contract contains counter-revolutionary content against the government (vi). Well, wait for the open-minded artist to come back (vii). Where on earth has he vanished so quickly (viii)?

All utterances in this conversation appear in the form of narration, but in fact, only (i) is the narrator's act of narrating while (ii) through (viii) are speech acts of the characters in the conversation, i.e. they are direct utterances of the characters.

\subsection{Context}

In many instances, especially RS without lead-in, or with lead-in but without graphics, it is necessary to rely on contexts, to trace each word of the narrator or characters in order to identify $\mathrm{RS}$.

\subsection{Perspective or vantage-point}

Foregrounded or backgrounded perspective or vantage points can help identify RS. The character's vantage point always foregrounds the active situation in question while that of the narrator is backgrounded in nature because he/she is describing the situation surrounding the character (Nguyễn Thị Thu Thủy, 2016b).

\section{Conclusion}

Studies of RS can assume different approaches. This study is based on the 
position that RS is a rhetorical device in literary works. As the results reveal, only those RSs which intentionally diverge from conventions can exert rhetorical impacts. Thus, the study explores breakthroughs in $\mathrm{RSs}$ in order that novel expressive values can be generated. The results assert that the view of RS as a rhetorical device is fully grounded.

It is possible to identify RRS thanks to their unconventional features. For instance, Nguyễn Huy Thiệp's RRSs are unconventional in RS organization (all RSs are separated from narrating parts, and are the focus of narration. Lead-in's ensure the $\mathrm{S}+\mathrm{V}$ model, which are short and normally contain ellipses of S; the quotes are also short and may not be relevant to the utterances of other interlocutors) (Nguyễn Thị Thu Thủy, 2016a). By contrast, Hồ Anh Thái's RRSs are either incomplete or without graphics, or mixed and blended with narration. Furthermore, what leads to strong impressions on the reader is the simultanousness and synergy of RRSs, which is intentional by the author.

\section{References}

\section{Vietnamese}

Hoàng Thị Bình (1998). Các phương thức tổ chức lời nói bên trong của nhân vật trong truyện ngắn Việt Nam hiện đại (Internal organization of characters' utterances in Vietnam 's short stories). Luận văn thạc sỹ. Hà Nội: Trường Đại học Sư phạm Hà Nội.

Phạm Vĩnh Cư (tuyển chọn, dịch từ nguyên bản tiếng Nga) (1992). Lý luận và thi pháp tiểu thuyết của Bakhtin (Bakhtin's theoretical issues and poetics of novels). Hà Nội: Trường Viết văn Nguyễn Du.

Nguyễn Thị Thu Thủy (2016a). Đặc điểm thoại dẫn trực tiếp trong truyện ngắn Nguyễn Huy Thiệp (Direct represented speech in Nguyen Huy Thiep's short stories). Tù điển hoc và Bách khoa thu (Encyclopedia and Lexicography), 36(2), 87-97.

Nguyễn Thị Thu Thủy (2016b). Điểm nhìn và ngôn ngũ trong truyện kể (Vantage point and language in narratives). Hà Nội: Nxb. Đại học Quốc gia Hà Nội.

\section{English}

Asher, R.E. (ed) (1994). Encyclopedia of Language and Linguistics. Vol.7. Oxford: Pergamon Press.

Black, Elizabeth (2006). Pragmatics Stylistics. Edinburgh: Edinburgh University Press.

Galperin, I.R. (1971). Stylistics. Moscow: Higher School Publishing House.

Genette, G. (1972). Figures III. Paris: Seuil.

Wales, K. (1989). A Dictionary of Stylistics. London, New York: Longman.

\section{Sources of data}

Hồ Anh Thái (2007). Mười lẻ một đêm (10+ nights). Đà Nẵng: Nxb. Đà Nẵng. 


\title{
THOẠI DẪN - MộT BIỆN PHÁP TU TỪ TRONG MƯỜI LẺ MỘT ĐÊM
}

\author{
Nguyễn Thị Thu Thủy
}

Truoòng Đại học Su phạm Hà Nội, 136 Xuân Thủy, Cầu Giấy, Hà Nội, Việt Nam

Tóm tắt: Thoại dẫn đã được nghiên cứu từ lâu trong ngôn ngữ học và phê bình văn học với nhiều quan điểm khác nhau. Từ cách tiếp cận phong cách học, chúng tôi nghiên cứu thoại dẫn trong truyện kể (trên ngữ liệu tiểu thuyết Muoơi lẻ một đêm của Hồ Anh Thái) nhằm làm rõ luận điểm của I.R.Galperin (1971) khi ông cho rằng thoại dẫn là một biện pháp tu từ. Bài viết có nhiệm vụ làm sáng tỏ các vấn đề: thế nào là biện pháp tu từ thoại dẫn, có phải tất cả các thoại dẫn trong tác phẩm văn chương đều là biện pháp tu từ không? Nếu không thì biện pháp tu từ thoại dẫn có những đặc điểm gì riêng? Phương pháp nghiên cứu chủ yếu được sử dụng là phương pháp phân loại (để phân loại các kiểu thoại dẫn), phương pháp miêu tả (để miêu tả các kiểu, các mô hình cấu tạo và đặc điểm ngôn ngữ của thoại dẫn...) và phân tích tu từ học (để phân tích giá trị tu từ, hiệu quả tu từ của một số trường hợp biện pháp tu từ thoại dẫn, làm rõ những luận điểm khoa học trong bài viết). Ngữ liệu được chọn nghiên cứu là những thoại dẫn trực tiếp có hình thức dẫn không theo quy chuẩn thông thường. Bài viết gồm có bốn phần: khái niệm biện pháp tu từ thoại dẫn, thoại dẫn tu từ trong Mười lẻ một đêm, cách xác định thoại dẫn tu từ trong Mười lẻ một đêm, và kết luận.

Tù khóa: thoại dẫn, biện pháp tu từ, truyện kể, phong cách học, lời dẫn 